\title{
KOMPARASI IMPLEMENTASI EKONOMI KERAKYATAN DI SEKTOR KELAUTAN DAN PERIKANAN
}

\section{Comparative Implementation of People's Economy in the Marine and Fisheries Sector}

\author{
*Nining I Soesilo \\ Fakultas Ekonomi dan Bisnis Universitas Indonesia \\ Gedung Dekanat FEB UI Kampus Widjojo Nitisastro, \\ JI. Prof. DR. Sumitro Djojohadikusumo, Kota Depok, Jawa Barat 16424, Indonesia \\ Diterima tanggal: 5 Maret 2021; Diterima setelah perbaikan: 20 Juni 2021; \\ Disetujui terbit: 25 Juni 2021
}

\begin{abstract}
ABSTRAK
Makalah ini memuat evaluasi tentang implementasi berbagai kebijakan ekonomi kerakyatan di sektor kelautan dan perikanan di Indonesia, sebagaimana diamanatkan oleh TAP MPR Nomor XVI/ MPR/1998. Meski tidak terdukung oleh ketersediaan data dan bersifat sangat umum, pencapaian ekonomi kerakyatan dalam sektor kelautan dan perikanan dapat diukur dan dirinci menurut analisis kurun waktu dengan penggunaan logika, pola dan metode perhitungan yang sama. Dalam penelitian ini, pengukuran pencapaian tersebut dilakukan dengan pendekatan keunggulan komparatif dari tren data pada setiap periode kebijakan menteri. Ada empat skenario evaluasi ekonomi kerakyatan yang diamati, yang diturunkan dari ketentuan TAP MPR tersebut di atas: (i) Skenario A, yang berorientasi pada masyarakat paling bawah dan koperasi melalui pendekatan nilai tukar nelayan dan jumlah ikan yang dijual di Tempat Pelelangan Ikan; (ii) Skenario B, yaitu skenario A yang ditambah dengan elemen perusahaan dalam negeri dan perusahaan lainnya; (iii) Skenario C, yaitu Skenario B yang ditambah dengan komparasi perusahaan asing; (iv) Skenario D, yaitu Skenario C yang ditambah dengan elemen ekspor impor. Hasil menunjukkan bahwa setiap skenario memiliki periode terbaiknya. Skenario A terbaik adalah terjadi pada periode kebijakan tahun 2011-2014. Skenario B dan C terbaik adalah terjadi pada periode kebijakan tahun 2014-2019. Sementara itu, Skenario D terbaik adalah terjadi pada periode kebijakan 2011-2014. Implikasi dari penelitian ini adalah bahwa apabila didukung ketersediaan data, pendekatan ini dapat direplikasi untuk terlaksananya implementasi ekonomi kerakyatan yang lebih baik di Indonesia.
\end{abstract}

Kata Kunci: analisis kurun waktu; ekonomi kerakyatan; kelautan dan perikanan; komparasi implementasi kebijakan; pemerintahan yang baik

\section{ABSTRACT}

This paper reports a bottom-up comparative evaluation of policy implementation on people's economy in Indonesia as regulated in TAP MPR Number XVI/ MPR /1998. Albeit lack of data, this experiment shows that the achievement of people's economy's can be detailed in marine and fishery sector by using similiar time series analysis with the same logic and methodology. The trend's comparative advantage of statistical data for each ministerial period is calculated. There are four scenarios to achieve multi-goals: (i) The A Scenario, the pro-poor implementation orientation is calculated using the exercise of exchange rate of fishers and the number of fish sold at the Fish Auction Center; (ii) The B Scenario, which is Scenario A added by elements of domestic companies and other companies; (iii) The C Scenario, which is the sum of the B scenario by including the comparison of foreign companies; (iv)The D Scenario, which is the C Scenario plus export and import activities. Each scenario has its best period. The best $A$ scenario was in the 2011-2014 period. The best B and C scenarios were between 2014-2019, and the best $D$ scenario was in the 2011-2014 period. The implication of this research is that if supported by the availability of data, this approach can be replicated for a better implementation of the people's economy in Indonesia.

Keywords: time series analysis; people's economy; marine and fisheres; comparative implementation policy; good governance. 


\section{PENDAHULUAN}

Pembangunan ekonomi kerakyatan yang berorientasi pada kelautan dan perikanan muncul dan berkembang berdasarkan pada lima landasan legal yang dibuat sesudah terjadinya krisis moneter 1998. Pertama, tercantum dalam TAP MPR Nomor XVI/MPR/1998 tentang 'Demokrasi Ekonomi' yang mengharuskan keberpihakan Indonesia pada 'pengembangan ekonomi rakyat yang mencakup koperasi usaha kecil dan menengah sebagai pilar utama pembangunan ekonomi nasional.' ${ }^{1}$ Kedua, mengingat kelautan sudah terlalu lama diabaikan (Trihartono, $\mathrm{H}$ ara \& Iqbal, 2018), maka diperlukan adanya kementerian khusus Departemen Eksplorasi Laut (DEL) dalam Kabinet Periode 19992004 sebagaimana Kepres No.355/M tanggal 26 Oktober 19992.Ketiga, pembentukan Departemen Eksplorasi Laut sesuai Kepres Nomor 136 Tahun 1999 pada 10 November 1999 tentang kedudukan, tugas, fungsi, susunan organisasi, dan tata kerja departemen. ${ }^{3}$ Keempat, Keputusan Presiden Nomor 165 Tahun 2000 tanggal 23 November 2000 tentang Departemen Kelautan dan Perikanan. Kelima, Peraturan Presiden No. 47 tahun 2009 tentang Nomenklatur Departemen Kelautan dan Perikanan menjadi Kementerian Kelautan dan Perikanan.

Demokrasi Indonesia berbeda dengan demokrasi di negara lain sebagaimana diawali di Yunani, yang kemudian menjadi rujukan umum untuk pelaksanaan demokrasi di dunia (Sen, 2003). Indonesia menyesuaikan demokrasi umum tersebut dengan sila keempat Pancasila yaitu "kerakyatan yang dipimpin oleh hikmat kebijaksanaan dalam permusyawaratan perwakilan'. Inilah yang menyebabkan dibentuknya Majelis Permusyaratan Rakyat (MPR) dalam demokrasi di Indonesia yang bertugas memberikan konsultasi (Keller, 2020) dan merupakan kumpulan dari perwakilan (Kelsay, 2002). Fungsi ini menjadikan TAP MPR XVI/MPR/1998 menjadi penting, terutama saat menyatakan "bahwa pelaksanaan amanat Demokrasi Ekonomi sebagaimana dimaksud dalam Pasal 33 Undang-Undang Dasar 1945 belum terwujud."
"Perangkap kemiskinan" (Sachs et al., 2004) banyak dijumpai di pesisir Indonesia, juga di berbagai negara berkembang lain (Panayotou, 1982); bahkan di negara majupun dijumpai (MacKenzie, 1979), sehingga penyelesaiannya membutuhkan pendekatan "pembangunan perikanan multi tujuan" (Charles dan Yang, 1991). Oleh karena itu, TAP MPR Nomor XVI/ MPR/1998 juga memiliki banyak tujuan. Meskipun berbicara tentang ekonomi kerakyatan, misalnya, saat membangun keberpihakan yang tegas ke pengusaha ekonomi lemah dan koperasi (pasal 4), juga tetap mengharapkan peranan usaha besar dan Badan Usaha Milik Negara (dipasal 5). Kemudian, untuk memulihkan perekonomian, maka di pasal 10 dan 11 disebutkan bahwa perlu adanya pinjaman luar negeri yang diatur agar tidak membahayakan perekonomian nasional. Kemudian, pasal 12 mengatur tentang "penanaman modal asing yang sekaligus diharapkan dapat menjalin keterkaitan usaha dengan pelaku ekonomi rakyat" ${ }^{\text {. }}$ Hal ini mengakibatkan perubahan nomenklatur DEL yang terjadi beberapa kali. Dengan dimasukkannya kata perikanan, maka nomenklatur terakhir menjadi Kementerian Kelautan dan Perikanan (KKP), yang memiliki visi Terwujudnya Masyarakat Kelautan dan Perikanan yang Sejahtera dan Sumber Daya Kelautan dan Perikanan yang Berkelanjutan untuk "Mewujudkan Indonesia Maju yang Berdaulat, Mandiri, dan Berkepribadian, berlandaskan Gotong Royong"5. Yang dimaksud dengan gotong royong disini adalah persatuan yang merujuk pada sila ketiga Pancasila yaitu 'Persatuan Indonesia' (Permana \& Mursidi, 2020).

Komparasi kinerja implementasi kebijakan publik sebenarnya memiliki dua pendekatan analisis, tetapi pendekatan "institusionalisme yang berpusat pada aktor" tidak dikupas di sini. Penelitian ini menekankan evaluasi "kebijakan publik komparatif" atau "analisis kebijakan komparatif" (Geva May, 2018, Schmidt 1997, 2003 dalam Saretzki 2007) yang membutuhkan 'kesamaan logika', 'mengasumsikan pola tertentu' meskipun tidak harus memiliki 'metodologi umum' (Lodge 2007: 275). Hal ini merupakan metode 'aksiomatik' Anglo-Amerika dan merupakan aliran 'ilmu keras' (hard science) (Solow 1985:

\footnotetext{
1,4https://m.hukumonline.com/pusatdata/detail//t508e1956c806b/node/657/ketetapan-majelis-permusyawaratan-rakyat-nomor-xvimpr-1998-tahun-1998

2,3https://kkp.go.id/page/6-sejarah

${ }^{4}$ https://kkp.go.id/page/7-visi-dan-misi x.
} 
328; Geva-May 2002: 246). Studi komparatif umumnya berorientasi internasional, misalnya tentang OECD (The Organisation for Economic Co-operation and Development) dengan metode RIA (Regulatory Impact Analysis)6. Demikian pula Indeks Kemudahan Berbisnis (Ease of Doing Business) oleh Bank Dunia (World Bank, 2020). Indeks Kemudahan Bisnis (IKB) merupakan analisis dari bawah ke atas dari kebijakan publik yang proses pembuatannya tidak langsung bagus, tetapi mengalami perbaikan terus menerus setelah melewati growing pain atau upaya jatuh bangun (Besley 2015). Namun demikian, Devadiga (2017) menyatakan bahwa IKB adalah penelitian yang 'penuh dengan kekurangan metodologis,' lebih mencerminkan 'pencapaian' para politisi daripada kenyataan, ada bias sampel, terlalu banyak asumsi, dan adanya masalah di implementasi. Studi komparatif yang ada di paper ini terilhami IKB dan dibuat dengan semangat terus memperbaiki, meski harus mengalami jatuh bangun, agar dapat lebih disempurnakan lagi oleh penelitian-penelitian selanjutnya. Di Indonesia, penerapan analisis komparatif melalui kajian penampang (cross section) sudah dilakukan oleh Kementerian Pemberdayaan Aparatur Negara dan Reformasi Birokrasi (PANRB) dan Unit Kerja Pengawasan dan Pengendalian Pembangunan (UKP4). Kegiatan Kementerian PANRB sampai saat ini masih berlangsung berdasarkan Perpres 29 Tahun 2014 tentang Sistem Akuntabilitas Kinerja Instansi Pemerintah (SAKIP) dan PermenPAN RB Nomor 53 Tahun 2014 Laporan Kinerja Instansi Pemerintah (LAPKIN)7. Adapun UKP4 lebih untuk mengawasi dan mengendalikan jalannya pembangunan (Pasal 3 Perpres 54/2009), yang hasilnya langsung dilaporkan ke presiden (Akuntono, 2014). Pada tahun 2021, Kementrian PANRB melakukan SAKIP dan RB terhadap 84 kementerian dan lembaga, 34 pemerintah provinsi serta 514 kabupaten yang dipublikasikan ke umum (Menpan.go.id, 2021), sedangkan UKP4 sudah dibubarkan sejak presiden Jokowi menggantikan presiden SBY. Penelitian ini berbeda dengan kegiatan PANRB dan UKP4 yang memakai analisis penampang, karena kajian pada makalah ini berdasarkan kurun waktu dan fokus materinya lebih ke implementasi ekonomi kerakyatan.
Indeks Kemudahan Berbisnis (IKB) telah mendorong hampir sepuluh juta orang setiap tahun untuk mengakses situs web Bank Dunia (Besley, 2015), menjadikanya sebagai kampanye arus utama (Capano, 2020, Geva-May, 2018) dan menjadi acuan politik (Feiock et al., 2008). Pada era kabinet Indonesia Maju II, pemerintah membuat kebijakan yang tertuang dalam 'omnibus law', karena terdorong oleh rendahnya IKB Indonesia, yang berada di peringkat 70 dari 180 negara; sehingga presiden menerapkan berbagai kebijakan untuk menjadikan Indonesia segera berada di peringkat 40 (Asmara, 2020). Belajar dari 'kesuksesan' IKB karya Bank Dunia yang telah diaplikasikan dalam 'ekonomi politik pembuatan kebijakan' di dunia (Besley, 2015) dan mampu menciptakan 'pergantian wawasan' (Capano, 2020) bagi para pemimpin berbagai negara di dunia, maka penelitian ini juga dimaksudkan untuk membuka peluang terobosan dalam evaluasi implementasi ekonomi kerakyatan di sektor kelautan dan perikanan. Kemudian, logika dan pola dalam topik yang sama bisa direplikasi untuk periode waktu berbeda di institusi pengelola sektor kelautan dan perikanan maupun sektor lain.

Selain membuat komparasi kurun waktu, penelitian ini juga mengevaluasi implementasi dari bawah ke atas (bottom-up) dari data yang ada, disesuaikan dengan konsep dan legalitas ekonomi kerakyatan yang berlaku, sesuatu yang belum banyak dilakukan di Indonesia. Penelitian ini mengadopsi pendekatan yang dilakukan Bank Dunia terkait IKB, yang dimodifikasi dan disesuaikan dengan TAP MPR XVI/MPR/1998. Bagian dari TAP MPR tersebut yang paling relevan dengan penelitian ini adalah falsafah dasar Pancasila dan pasal 33 ayat 3 UUD 45, yang menjadi rujukan ekonomi kerakyatan dan diramu dalam visi misi kementerian. Untuk memelihara keberlanjutan analisisnya, maka inovasi perlu dilakukan (Domínguez-Escrig et al., 2019). Oleh karena itu, dibuatlah empat skenario $(A, B, C$ dan $D)$, yang merupakan proses pemahaman dari kalimat-kalimat yang tertera di pasal-pasal TAP MPR XVI/MPR/1998.

Artikel ini menganalisa secara kuantitatif perhitungan keunggulan komparatif (persamaan 6) yang diolah dari 'trend' persamaan linier (persamaan 1) hasil olahan data dari variabel-

\footnotetext{
${ }^{6}$ https://www.oecd.org/gov/regulatory-policy/ria.htm

${ }^{7}$ http://www.bpkp.go.id/puslitbangwas/konten/2019/LAKIP
} 
variabel yang diturunkan dari TAP MPR XVI/ MPR/1998 yang membentuk skenario $A, B, C$ dan $\mathrm{D}$ dari ekonomi kerakyatan. Analisa kemiringan garis atau 'slope' dari trend data statistik ekonomi kerakyatan (persamaan 5) menjadi proksi keberhasilan implementasi kebijakan. Karena TAP MPR memiliki kisi-kisi multi tujuan, maka dibuatlah empat skenario sebagai berikut:

1. Skenario A adalah ekonomi kerakyatan yang dikaitkan dengan koperasi dan usaha tak berbadan hukum seperti terlihat di aktivitas para nelayan sebagai kelompok termiskin. Karena informasi tentang koperasi tidak cukup tersedia, maka digunakanlah data Nilai Tukar Nelayan (NTN) dan penjualan ikan di Tempat Pelelangan Ikan (TPI). Skenario ini merupakan terjemahan dari alenia 'menimbang' di butir b, serta dari pasal 7 ayat 1 dari TAP MPR XVI/MPR/1998.

2. Skenario B adalah ekonomi kerakyatan yang dikaitkan dengan prestasi usaha mikro kecil menengah berbadan hukum, serta pengusaha besar nasional. Dalam hal ini, dilakukanlah penjumlahan angka komparasi trend dari NTN + TPI + jumlah perusahaan PMDN + perusahaan lainnya. Ini merupakan penjumlahan dari skenario $A$ dengan variabel yang dihasilkan dari interpretasi pasal 2 dan pasal 5 TAP MPR XVI/MPR/1998.

3. Skenario $C$ adalah adalah ekonomi kerakyatan yang merupakan penjumlahan skenario B dengan kontribusi keunggulan komparatif perusahaan penanaman modal asing (PMA), yang merupakan penterjemahan dari pasal 12 TAP MPR XVI/MPR/1998.

4. Skenario $D$ adalah ekonomi kerakyatan yang mengaitkan semua elemen yang sudah dirinci di atas, yaitu menjumlahkan nilai komparatif skenario C dengan keunggulan komparatif ekonomi kerakyatan di bidang expor dikurangi impor atau nett export, yang diterjemahkan dari pasal 2, 5 dan 6 TAP MPR XVI/MPR/1998.

Persamaan garis trend yang dipakai komparasi memiliki bentuk persamaan sebagai berikut

$$
\hat{y}=a+b t
$$

dimana ẏ adalah data kurun waktu yang akan diperkirakan. Kemudian, $\mathrm{t}$ adalah variabel waktu, sedangkan a adalah intersep dan b adalah slope atau kemiringan garis trend. Adapun $a$ dan $b$ didapat dengan memakai rumus persamaan 2,3,4 dan 5 sebagai berikut:

$$
\begin{gathered}
a=\bar{y}-b \bar{t} \\
\bar{y}=\frac{\sum y}{n} \\
\bar{t}=\frac{\sum t}{n} \\
b=\frac{\sum t y-\frac{\sum t \sum y}{n}}{\sum t^{2}-\frac{\left(\sum t\right)^{2}}{n}} \\
\text { comparative trend }{ }_{i}^{t}=\frac{b_{i}^{t}}{\sum_{t=1}^{n} b_{i}^{t}}
\end{gathered}
$$

Persamaan 5 adalah angka trend dari persamaan linier. Bila angkanya makin besar berarti ada kecepatan yang bertambah seiring perjalanan waktu di periode yang diteliti. Persamaan 6 adalah rumus comparative trend, yang mana notasi $\mathrm{i}$ adalah nama periode kepemimpinan seorang menteri; notasi t adalah kurun waktu dan $\mathrm{n}$ adalah jumlah menterinya. Studi komparasi ini memakai persamaan linier untuk semua periode. Keseragaman ini dibuat supaya hasilnya bisa dibandingkan satu sama lain dari angka trend-nya, karena ada 'kesamaan logika' dan 'asumsi pola tertentu' (Lodge, 2007). Meski demikian, koefisien determinasi $R^{2}$ ini tidak diperhatikan atau dianalisa agar supaya tetap bisa mengambil kesimpulan mengingat keterbatasan data. Koefisien determinasi ini merupakan sumbangan pengaruh yang diberikan variabel bebas atau independent variable $\mathrm{t}$ terhadap variabel terikat atau dependent variable $(\mathrm{Y})$ dari persamaan 1 (Worley et al., 1993).

Adapun data yang dipakai sebagai bahan analisis dipindai dari tiga sumber yaitu dari situs web KKP, dari BPS, dan dari situs web Bank Indonesia. Data yang dipilih adalah data yang memiliki kurun waktu yang cukup panjang sehingga bisa dilakukan perbandingan kinerja secara kurun waktu program-program sektor kelautam dan perikanan. Artikel ini juga sebagian memanfaatkan analisa berita di media massa dalam kurun waktu yang bersangkutan (Jann dan Wegrich, 2007). Alasannya adalah bahwa karena analisa ini tidak hanya menawarkan tolak ukur untuk evaluasi (komparatif) atas keberhasilan atau kegagalan suatu kebijakan melainkan juga menawarkan perspektif dalam mengevaluasi kualitas proses yang terjadi, apakah menentang demokrasi atau tidak. 


\section{SEJARAH PERKEMBANGAN INSTITUSI DI SEKTOR KELAUTAN DAN PERIKANAN}

Negara merupakan konsep normatif dan merupakan model tentang bagaimana kondisi terbaik dan terhormat dari suatu wilayah politik yang terorganisir yang dilakukan oleh bangsa (Wright, 2011a, 2011b). Pada tahun 1998, Indonesia mulai memberi fokus pada sumber daya kelautan dan perikanan. Sebelumnya, selama bertahun-tahun terdapat kesalahan paradigmatik dalam pembangunan kelautan Indonesia, yang menempatkan laut dari aspek ancaman militer keamanan, tetapi belum mendesak untuk menggarap kepentingan pengembangan dan kemajuan perekonomiannya (Trihartono, Hara \& Iqbal, 2018). Sejak era reformasi, sektor kelautan mulai mendapat perhatian melalui terbentuknya DEL yang kemudian diubah menjadi DELP dan kemudian diubah menjadi DKP. Terakhir, intitusi ini berubah nomenklatur menjadi menjadi Kementerian Kelautan dan Perikanan (KKP).

Dari awal berdirinya, KKP merupakan kementerian yang penuh dinamika, dimana terdapat sejumlah pergantian menteri dalam kurun waktu yang tidak terlalu lama (Tempo.co, 2003; Yusuf \& Sumner, 2015). Pada 2014, Presiden memperkenalkan kebijakan pengembangan ekonomi kerakyatan untuk menanggulangi kemiskinan (Yusuf \& Sumner, 2015), dan percepatan pembangunan Indonesia (Warburton, 2016).

\section{PARADIGMA PEMBANGUNAN EKONOMI BERBASIS SUMBER DAYA KELAUTAN PERIKANAN KE EKONOMI BIRU}

Gelombang kedua perkembangan studi implementasi kebijakan terjadi pada era 1990-an, didorong oleh permasalahan kebijakan lingkungan di Eropa dan diwarnai oleh pengaruh karakter politik dari proses implementasi kebijakan. Inovasi teoritis dari studi ini adalah penggabungan kerangka kerja, argumen politik komparatif dan globalisme. Konsep tentang studi ini banyak diperbincangkan pada pertemuan Rio+20, yang oleh pemerintahan Presiden SBY kemudian ditindaklanjuti dengan sosialisasi buku yang menginspirasi pertemuan tersebut, yaitu 'Blue Economy' (Pauli, 2010). Mengacu pada Satria (2015), kata blue tersebut mengandung makna bersih, pengertian yang terinspirasi oleh aliran deep ecology dan fokus pada tata kerja alam (back to nature). Budi daya juga diubah misalnya diarahkan untuk praktik tanpa pakan, mengembalikannya ke arah trophic level.
Implementasi ekonomi biru ini membutuhkan inovasi (Domínguez-Escrig et al., 2019), yang kemudian terefleksikan dalam visi misi institusi pengelola sektor kelautan dan perikanan. Mulai tahun 2014, konsep ini tidak banyak diungkapkan secara eksplisit, tetapi terdapat kebijakankebijakan yang selaras dengan ekonomi biru, misalnya kebijakan larangan penangkapan benih lobster, yang membiarkan benih lobster tetap besar di alam. Kemudian, terdapat kebijakan anti illegal fishing. Salah satu bentuk konkret kebijakan tersebut adalah pelarangan cantrang melalui Peraturan Menteri Nomor 2/PERMENKP/2015 karena dianggap merusak habitat ikan (Sutari, 2017). Namun, kebijakan peyelamatan bumi secara drastis sebagai tujuan utama ternyata membawa ke dua kutub ekstrim yang tidak sejalan dengan konsep "multi tujuan" pembangunan perikanan (Charles dan Yang 1991, hlm. 294). Memerangi illegal fishing membawa banyak dampak positif di satu sisi, tetapi juga berakibat negatif di sisi lain, misalnya kehidupan nelayan tertentu. Hal ini terefleksikan dalam berbagai tentangan dari nelayan terdampak yang membawa hingga 10 jenis tuntutan (Sutari, 2017).

Penelitian komparasi implementasi kebijakan ekonomi kerakyatan ini sangat membutuhkan data yang lengkap akurat. Saretzki (2007) mengatakan bahwa analisis komparasi kebijakan sangat berkembang di kalangan negara-negara EOCD, terutama karena data internasional jauh lebih mudah didapat. Untuk konteks Indonesia, ketersediaan data ini akan menjadi tantangan tersendiri.

\section{Kebutuhan Data untuk Analisa Komparasi Implementasi Kebijakan}

Dalam penelitian ini, data yang digunakan berasal dari tiga sumber yaitu situs web KKP, BPS dan Bank Indonesia. Penggunaan data tunggal, misalnya dari KKP, harus dihindari karena sebagaimana dikatakan oleh Satria (2015), data-data tentang perikanan di Indonesia masih memiliki banyak bias (Satria, 2015). Oleh karena itu, pemerintah membuat portal 'Satu Data Indonesia' (SDI) untuk seluruh data pemerintah dan data instansi terkait. Satu Data Indonesia (SDI) dapat diakses secara bebas sebagaimana diatur dalam UU nomor 14 Tahun 2008 tentang Keterbukaan Informasi Publik (https://data.go.id/tentang). Ringkasan pemakaian data yang digunakan dalam penelitian ini terlihat pada Tabel 1. Data BPS pada tahun 2019 mencatat bahwa dari 383 
Tabel 1. Data yang Dipakai Dalam empat Perhitungan Komparasi Skenario Implementasi. Table 1. Data Being Used for Four Comparative Implementation Scenarios.

\begin{tabular}{|c|c|c|c|}
\hline No & $\begin{array}{l}\text { Data yang dipakai Komparasi/ } \\
\text { Data Being Used for Comparison }\end{array}$ & $\begin{array}{l}\text { Kurun Waktul } \\
\text { Period }\end{array}$ & Sumber/Source \\
\hline 1 & Nilai Tukar Nelayan/Fishermen's of Trade & $2008-2021$ & $\begin{array}{l}\text { https://satudata.kkp.go.id dan } \\
\text { Permintaan khusus ke Pusdatin } \\
\text { di KKP (with a special request to } \\
\text { Data Center at MMAF ) }\end{array}$ \\
\hline 2 & Penjualan ikan di TPI/Fish sold in Fish Auction Sites & $2000-2019$ & https://www.bps.go.id/ \\
\hline 3 & $\begin{array}{l}\text { Perusahaan PMDN dan lainnya/Number of Domestic } \\
\text { and Other Types of Company in Fishery }\end{array}$ & $2000-2019$ & https://www.bps.go.id/ \\
\hline 4 & $\begin{array}{l}\text { Perusahaan PMA/Number of Foreign Company in } \\
\text { Fishery }\end{array}$ & $2000-2019$ & https://www.bps.go.id/ \\
\hline 5 & Export ikan dalam USD/Fish export in USD & $2000-2020$ & $\underline{\text { www.bi.go.id data bulanan }}$ \\
\hline 6 & Export ikan dalam Ton/Fish export in tons & $2000-2020$ & \\
\hline 7 & Export ikan dalam USD/Fish export in USD & $2000-2020$ & \\
\hline 8 & Export ikan dalam To/nFish export in tons & $2000-2020$ & \\
\hline
\end{tabular}

perusahaan perikanan di Indonesia, hanya enam yang berbentuk koperasi, dan datanya hanya tersedia di tahun 2019 (Tabel 2) (Gambar 1) ${ }^{8}$. Oleh karena itu, mustahil untuk dibuat komparasinya. Berdasarkan data BPS, mayoritas pekerja dari perusahaan-perusahaan tersebut merupakan tamatan SMA. Oleh karena itu, maka skenario A pada Tabel 1 dan 2 didekati dari data lain, yaitu tentang aktivitas kegiatan rakyat kecil yang tercatat dari nilai tukar nelayan (NTN) dan penjualan ikan di TPI.

Tabel 2. Jumlah Koperasi Sektor Perikanan di Indonesia Tahun 2019 Versi Data BPS.

Table 2. The Number of Cooperatives in Indonesia's Fishery Sectors in 2019, according to BPS.

\begin{tabular}{cccccccc}
\hline $\begin{array}{c}\text { Aktivitas/ } \\
\text { Activity }\end{array}$ & $\begin{array}{c}\text { PN/PD/ } \\
\text { Persero }\end{array}$ & PT/NV & CV & Firma & $\begin{array}{c}\text { Koperas/ } \\
\text { Cooperatives }\end{array}$ & $\begin{array}{c}\text { Lainnya/ } \\
\text { Others }\end{array}$ & $\begin{array}{c}\text { Jumlah/ } \\
\text { Total }\end{array}$ \\
\hline Penangkapan/Fishing & 15 & 74 & 6 & 1 & 6 & 2 & 104 \\
Pembudi daya/Aquaculture & 9 & 183 & 70 & 1 & 0 & 16 & 279 \\
\hline Total & $\mathbf{2 4}$ & $\mathbf{2 5 7}$ & $\mathbf{7 6}$ & $\mathbf{2}$ & $\mathbf{6}$ & $\mathbf{1 8}$ & $\mathbf{3 8 3}$ \\
\hline
\end{tabular}

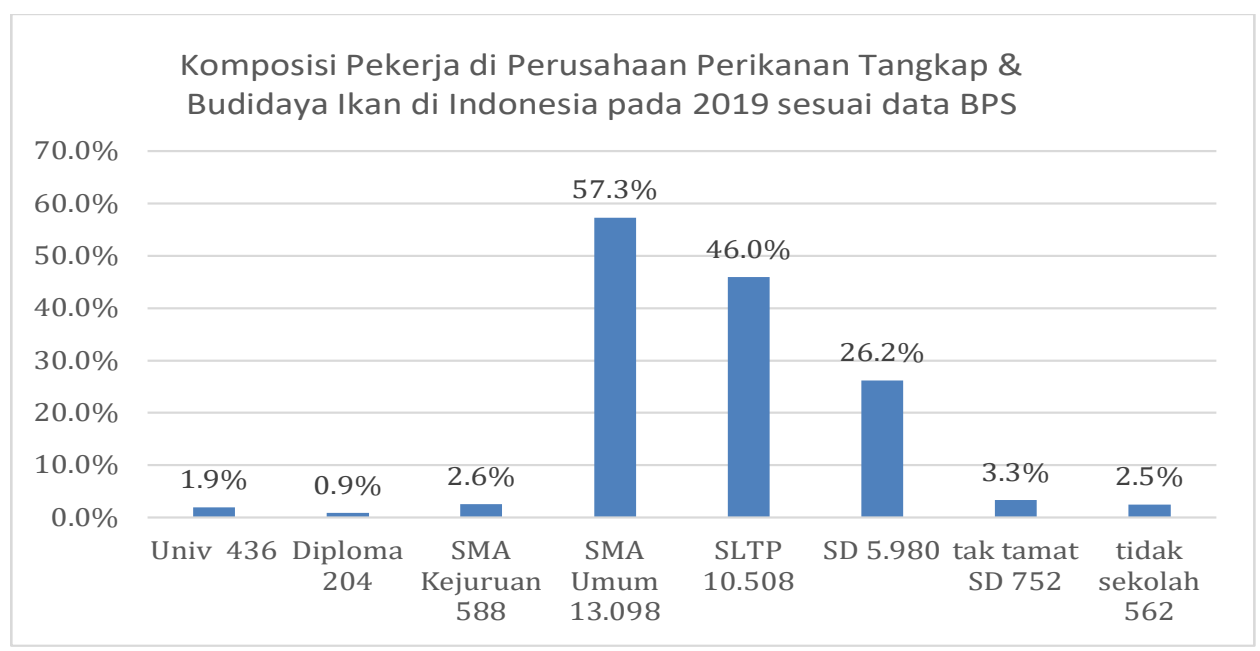

Gambar 1. Pendidikan Para Pekerja Perusahaan Perikanan di Indonesia 2019.

Figure 1. Education Level of Fisheries Companies' Workers in Indonesia 2019. 


\section{EVALUASI IMPLEMENTASI EKONOMI KERAKYATAN SEKTOR KELAUTAN DAN PERIKANAN}

\section{Implementasi Skenario A Ekonomi Kerakyatan}

Skenario A dari implementasi ekonomi kerakyatan sektor kelautan dan perikanan didekati dari jumlah keunggulan komparatif dari trend Nilai Tukar Nelayan (NTN) dan keunggulan komparatif trend jumlah ikan yang dijual di TPI. Nilai Tukar Nelayan (NTN) merupakan angka rasio (bentuk persentase) dari indeks harga yang diterima nelayan (It) dengan angka indeks harga yang dibayar nelayan (Ib). NTN digunakan untuk mengetahui kemampuan tukar ikan hasil tangkapan terhadap barang/jasa yang diperlukan untuk kebutuhan produksi maupun kebutuhan konsumsi rumah tangga. Data ikan yang terjual di Tempat Pelelangan Ikan (TPI) tersedia di situs web BPS.
Adapun rincian dari Tabel 3 dapat dilihat dari Tabel 4 dan Tabel 5 yang mana merupakan rincian dari komparasi trend dari persamaan linier dari Nilai Tukar Nelayan (NTN) dan juga bagi komparasi trend dari ikan dijual di TPI.

\section{Implementasi Skenario B Ekonomi Kerakyatan}

Skenario B implementasi ekonomi kerakyatan sektor kelautan dan perikanan (terlihat di Tabel 6) merupakan penggabungan skenario $\mathrm{A}$ : penjumlahan keunggulan trend NTN+TPI seperti terlihat di Tabel 3 ditambah dengan keunggulan komparatif trend perusahaan perikanan berbentuk Penanaman Modal Dalam Negeri (PMDN) seperti terlihat di Tabel 7, dan perusahaan perikanan lainnya di Tabel 8. Keseluruhan elemen skenario B terlihat di Tabel 6.

Tabel 3. Ringkasan Keunggulan Komparatif Perbandingan Trend Skenario A.

Table 3. The Summary of Comparative Trend of the A Scenario.

\begin{tabular}{ccccc}
\hline Periode/Period & NTN & TPI & Total Skenario A & Status \\
\hline $2004-2009$ & 0.007754 & 1.949967 & 1.957721 & \\
$2009-2011$ & 0.001303 & -2.7104 & -2.7091 & Terendah/ Lowest \\
$2011-2014$ & 0.437965 & 3.098023 & 3.535988 & Tertinggi/ Highest \\
$2014-2019$ & 1.86291 & 1.662414 & 3.525324 & \\
\hline
\end{tabular}

Tabel 4. Rincian Komparasi Keunggulan Komparatif dari Trend Nilai Tukar Nelayan. Table 4. Details of Comparative Trend of Fisherman's Exchange.

\begin{tabular}{|c|c|c|c|c|c|}
\hline \multicolumn{6}{|c|}{ Trend Kenaikan Nilai Tukar Nelayan/Fisherman Exchange Comparative Trend } \\
\hline $\begin{array}{c}\text { Periode/ } \\
\text { Period }\end{array}$ & Linear Equation & $\mathbf{R}^{2}$ & Slope & Comparative Trend & Status \\
\hline $2004-2009$ & $y=0.0125 x-395.28$ & 0.9036 & 0.0125 & 0.007754 & \\
\hline $2009-2011$ & $y=0.0021 x+21.582$ & 0.6646 & 0.0021 & 0.001303 & \\
\hline $2011-2014$ & $y=0.353 x+90.141$ & 0.8074 & 0.353 & 0.437965 & Tertinggi/Highest \\
\hline $2014-2019$ & $y=0.1616 x+91.868$ & 0.946 & 0.1616 & 0.200496 & \\
\hline $2019-2020$ & $y=0.0158 x+100.03$ & 0.0053 & 0.0158 & 0.019603 & Terendah/Lowest \\
\hline $2020-$ now & $y=0.261 x+102.04$ & 0.4721 & 0.261 & 0.323821 & \\
\hline \multicolumn{2}{|c|}{ Rerata kemiringan garis/Average slope } & & 0.806 & 1 & \\
\hline
\end{tabular}

Tabel 5. Detail Keunggulan Komparatif dari Trend Ikan yang Dijual di TPI.

Table 5. Detail of Comparative Trend of Fish Sold in Fish Auction Site.

\begin{tabular}{|c|c|c|c|c|c|}
\hline \multicolumn{6}{|c|}{ Trend Kenaikan Penjualan Ikan di TP/Increasing Trend of Fish Sold at Fish Auction Sites } \\
\hline Periode/Period & Linear Equation & $\mathbf{R}^{2}$ & Slope & Comparative Trend & Status \\
\hline 2004-2009 & $y=63235 x+275505$ & 0.9514 & 63235 & 1.949967 & \\
\hline 2009-2011 & $y=-87895 x+760412$ & 0.3268 & -87895 & -2.7104 & Terendah/lowest \\
\hline $2011-2014$ & $y=100465 x+297020$ & 0.8673 & 100465 & 3.098023 & Tertinggi/ highest \\
\hline 2014-2019 & $y=53910 x+478903$ & 0.7076 & 53910 & 1.662414 & \\
\hline Rerata kemiringan & aris/Average slope & & 32428.75 & 1 & \\
\hline
\end{tabular}


Tabel 6. Komparasi Trend Implementasi Ekonomi Kerakyatan Skenario B.

Table 6. Comparative Trend of the B Scenario of the People's Economy.

\begin{tabular}{crcccc}
\hline Periode/Period & $\begin{array}{c}\text { Skenario A/ } \\
\text { A Scenario }\end{array}$ & $\begin{array}{c}\text { PMDN*IDomestic }^{*} \\
\text { Company }\end{array}$ & $\begin{array}{c}\text { Lainnya**/Other } \\
\text { Types of Company }\end{array}$ & Skenario B & Status \\
\hline $2004-2009$ & 1.957721 & 0.868 & 0.391753 & 3.217474 & Lowest \\
$2009-2011$ & -2.7091 & 2.171 & 0.824742 & 0.286645 & Highest \\
$2011-2014$ & 3.535988 & -2.058 & 1.649485 & 3.127473 & 6.762345 \\
$2014-2019$ & 3.525324 & 2.103 & 1.134021 & &
\end{tabular}

Tabel 7. Keunggulan Komparatif dari Perusahaan PMDN.

Table 7. Comparative Advantage of Domestic Companies' Trends.

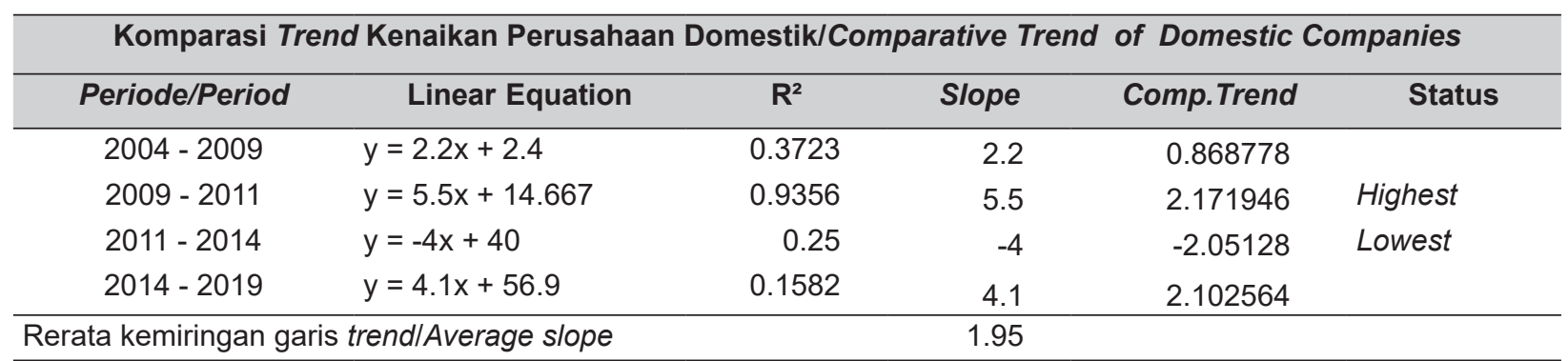

Tabel 8. Skenario Keunggulan Komparatif Trend dari perusahaan jenis lainnya.

Table 8. Trend's Comparative Advantage the Development of Other Companies'.

\begin{tabular}{|c|c|c|c|c|c|}
\hline Periode/Period & Persamaan Linier & $\mathrm{R}^{2}$ & Slope & Comp.Trend & Status \\
\hline $2004-2009$ & $y=1.9 x+15.1$ & 0.6588 & 1.9 & 0.391753 & Lowest \\
\hline $2009-2011$ & $y=4 x+20.667$ & 0.9796 & 4 & 0.824742 & \\
\hline $2011-2014$ & $y=8 x+22.333$ & 0.75 & 8 & 1.649485 & Highest \\
\hline $2014-2019$ & $y=5.5 x+13.3$ & 0.8623 & 5.5 & 1.134021 & \\
\hline
\end{tabular}

Rerata kemiringan garis trend/Average slope

Trend perbandingan pertumbuhan jumlah PMDN tertinggi ada di periode 2009-2011, terendah di periode 2011-2014. Trend pertumbuhan jumlah perusahaan berkategori lainnya tertinggi terjadi pada periode 2011-2014 dan terendah pada periode 2004-2009.

Implementasi Skenario C Ekonomi Kerakyatan.

Skenario C merupakan penjumlahan skenario B (NTN +TPI + PMDN + Lainnya) ditambah dengan angka comparative trend pertumbuhan perusahaan perikanan yang tercatat berbentuk sebagai Penanaman Modal Asing (PMA), sebagaimana terlihat di Tabel 9.

Rincian kinerja ringkasan ekonomi kerakyatan (Tabel 9), bila dilihat hanya dari keunggulan komparatif dari Penamanam Modal Asing saja dapat dilihat di Tabel 10.

Tabel 9. Ringkasan dari Skenario $\mathbf{C}$.

Table 9. Summary of the C Skenario.

\begin{tabular}{|c|c|c|c|c|c|c|c|}
\hline \multirow{2}{*}{ Period } & 1 & 2 & 3 & $4=1+2=3$ & 5 & $6=4+5$ & \multirow{2}{*}{ Status } \\
\hline & Skenario A & PMDN & Lainnya & Skenario B & PMA & Skenario C & \\
\hline $2004-2009$ & 1.958 & 0.869 & 0.392 & 3.218 & 0.457 & 3.675 & Lowest \\
\hline $2009-2011$ & -2.709 & 2.172 & 0.825 & 0.288 & 3.875 & 4.163 & \\
\hline 2011 - 2014 & 3.536 & -2.051 & 1.649 & 3.134 & 0.830 & 3.965 & \\
\hline $2014-2019$ & 3.525 & 2.103 & 1.134 & 6.762 & -1.163 & 5.599 & Highest \\
\hline
\end{tabular}

Catatan: kata dengan penebalan artinya tertinggi/Note:The bold words means the highest 
Tabel 10. Detil Keunggulan Komparatif Trend Perusahaan PMA Perikanan di Skenario C. Table 10. Detail Comparative Foreign Company Performance's trend in C Scenario.

\begin{tabular}{clrrrr}
\hline Period & Linear Equation & \multicolumn{1}{c}{$\mathbf{R}^{\mathbf{2}}$} & Slope & Comp.Trend & Status \\
\hline $2004-2009$ & $\mathrm{y}=1.1 \mathrm{x}+3.5$ & 0.6436 & 1.1 & 0.456763 & \\
$2009-2011$ & $\mathrm{y}=9.3333$ & 0 & 9.333 & 3.875428 & Highest \\
$2011-2014$ & $\mathrm{y}=2 \mathrm{x}+7$ & 1 & 2 & 0.830479 & \\
$2014-2019$ & $\mathrm{y}=-2.8 \mathrm{x}+16.2$ & 0.9245 & -2.8 & -1.16267 & Lowest \\
\hline Rerata kemiringan garis trend/Average slope & & & 2.40825 & \\
\hline
\end{tabular}

Dari Tabel 10, maka terlihat bahwa trend jumlah PMA tertinggi terjadi pada masa periode 2009-2011, terendah terjadi pada masa 2014-2019.

\section{Implementasi Skenario D Ekonomi Kerakyatan}

Skenario $D$ dari ekonomi kerakyatan adalah penjumlahan keunggulan comparative trend dari skenario C (yaitu NTN+TPI+PMDN+Lainnya+PMA) kemudian ditambah comparative trend dari kegiatan ekspor dan dikurangi impor sebagaimana terlihat di Tabel 11. Adapun detil uraian dari Tabel 11 mengenai komparatif kegiatan ekspor impor terlihat di Tabel 12. Secara rinci, hal ini terlihat dalam Tabel 13, 14, 15, 16 tentang ekspor ikan dan udang dalam USD dan ton, serta Tabel 17, 18, 19, 20 tentang impor ikan dan udang dalam USD dan ton. Terlihat bahwa trend penurunan nilai ekspor ikan dalam USD (rata rata slope -112.89) di Tabel 13 lebih rendah dibandingkan dengan penurunan volumenya (rata rata slope -0.37498) di Tabel 14. Hal ini menunjukkan adanya penurunanan harga rata-rata produk perikanan yang diekspor, antara lain disebabkan oleh sebagian besar komoditas ekspor masih mengarah pada produk bernilai tambah rendah (primary product).

Tabel 11. Keunggulan Comparative Trend Kinerja Ekonomi Kerakyatan Skenario D. Table 11. Comparative Trend Performance in D Scenario of the People's Economy.

\begin{tabular}{|c|c|c|c|c|c|c|c|}
\hline \multicolumn{3}{|c|}{$\begin{array}{l}\text { Skenario } D=\text { Skenario } C+\text { Ekspor }- \text { Imporl } \\
D \text { Scenario }=C \text { Scenario }+ \text { Export }- \text { Import }\end{array}$} & 2004-2009 & $2009-2011$ & 2011-2014 & 2014-2019 & $2019-2020$ \\
\hline $\begin{array}{l}\text { Ekspor Impor/Export and } \\
\text { Import }\end{array}$ & \multicolumn{2}{|c|}{$\begin{array}{l}\text { Comp. Trend } \\
\text { Skenario C }\end{array}$} & 3.67 & 4.16 & 3.96 & 5.59 & $\mathrm{Na}$ \\
\hline \multirow{4}{*}{$\begin{array}{l}\text { Ekspor Ikan/ } \\
\text { Fish Export }\end{array}$} & \multirow[t]{2}{*}{ USD } & Slope & $\mathrm{Na}$ & 885.11 & -475.63 & 752.76 & -1613.8 \\
\hline & & CTrend & $\mathrm{Na}$ & -7.84 & 4.21 & -6.67 & 14.29 \\
\hline & \multirow[t]{2}{*}{ Ton } & Slope & $\mathrm{Na}$ & -0.87 & -0.05 & 0.05 & -0.63 \\
\hline & & CTrend & $\mathrm{Na}$ & 2.32 & 0.13 & -0.14 & 1.69 \\
\hline \multirow{4}{*}{$\begin{array}{l}\text { Ekspor Udang/ } \\
\text { Shrimp Export }\end{array}$} & \multirow[t]{2}{*}{ USD } & Slope & $\mathrm{Na}$ & 1630.10 & 2294.60 & -3.88 & 1348.60 \\
\hline & & CTrend & $\mathrm{Na}$ & 1.24 & 1.74 & -0.003 & 1.02 \\
\hline & \multirow{2}{*}{ Ton } & Slope & $\mathrm{Na}$ & 0.00 & 0.00 & 0.00 & 0.00 \\
\hline & & CTrend & $\mathrm{Na}$ & 0.00 & 0.00 & 0.00 & 0.00 \\
\hline \multicolumn{2}{|l|}{ Total Ekspor/Total Export } & TotCT & $\mathrm{Na}$ & -4.28 & 6.08 & -6.82 & 17.01 \\
\hline \multirow{4}{*}{ Import Ikan/Fish Import } & \multirow[t]{2}{*}{ USD } & Slope & $\mathrm{Na}$ & 8.40 & 100.89 & 3.57 & 0.29 \\
\hline & & CTrend & $\mathrm{Na}$ & 0.29 & 3.57 & 0.13 & 0.01 \\
\hline & \multirow[t]{2}{*}{ Ton } & Slope & $\mathrm{Na}$ & -0.003 & 0.00 & 0.00 & 0.01 \\
\hline & & C Trend & $\mathrm{Na}$ & -1.36 & -0.14 & 0.00 & 5.50 \\
\hline \multirow{4}{*}{$\begin{array}{l}\text { Import Udang/ } \\
\text { Shrimp Import }\end{array}$} & \multirow{2}{*}{ USD } & Slope & $\mathrm{Na}$ & 216.09 & 61.51 & 70.81 & -106.90 \\
\hline & & CTrend & $\mathrm{Na}$ & 3.58 & 1.02 & 1.17 & -1.77 \\
\hline & \multirow[t]{2}{*}{ Ton } & Slope & $\mathrm{Na}$ & 0.02 & 0.002 & 0.004 & 0.00 \\
\hline & & CTrend & $\mathrm{Na}$ & 2.47 & 0.24 & 0.46 & 0.82 \\
\hline \multirow{2}{*}{\multicolumn{3}{|c|}{$\begin{array}{lr}\text { Imporf/Import } & \text { TotCT } \\
\text { Eksport-Import saja/Export and Import only }\end{array}$}} & $\mathrm{Na}$ & 4.99 & 4.69 & 1.76 & 4.56 \\
\hline & & & $\mathrm{Na}$ & -9.27 & 1.39 & -8.58 & 12.45 \\
\hline \multicolumn{3}{|l|}{ Skenario D/D Scenario } & $\mathrm{Na}$ & -5.11 & 5.36 & -2.98 & $\mathrm{Na}$ \\
\hline \multicolumn{3}{|l|}{ Status } & & Lowest & Highest & & \\
\hline
\end{tabular}


Hal sebaliknya terjadi pada kasus udang yang kenaikan trend ekspor udang dalam USD slopenya sebesar 1317.355 (Tabel 15), sedangkan kenaikan trend ekspor udang dalam ton, slopenya hanya 0.25975 (Tabel 16). Detail dari Tabel 11 mengenai kegiatan ekspor impor dalam USD dan ton terlihat di Tabel 12.
Di Tabel 13 terlihat bahwa comparative trend ekspor ikan dalam USD tertinggi terjadi pada periode 2009-2011 (slope 885.11) dan terendah pada periode 2019-2020 (slope -1613.8). Pada Tabel 17 sampai dengan Tabel 18 diuraikan tentang kegiatan impor ikan dan udang dalam USD maupun ton.

Tabel 12. Ringkasan Keunggulan Komparatif Trend Ekspor Impor Ikan Udang (USD dan Ton). Table 12. Summary of Comparative Trend of Export and Import of Fish and Shrimp in USD and Tons.

\begin{tabular}{|c|c|c|c|c|c|c|}
\hline \multirow{2}{*}{\multicolumn{2}{|c|}{$\begin{array}{l}\text { Total Comparative Trend of } \\
\text { Export-Import of fish and shrimp }\end{array}$}} & \multicolumn{5}{|c|}{ Periode/Period } \\
\hline & & $2004-2009$ & $2009-2011$ & 2011 - 2014 & $2014-2019$ & $2019-2020$ \\
\hline Total Ekspor/Total Export & TotCT & $\mathrm{Na}$ & -4.284 & 6.088 & -6.816 & 17.012 \\
\hline Total Impor/Total Import & TotCT & $\mathrm{Na}$ & 4.986 & 4.691 & 1.762 & 4.561 \\
\hline \multirow{2}{*}{\multicolumn{2}{|c|}{ Eksport-Import saja/Export-Import Only }} & $\mathrm{Na}$ & -9.270 & 1.397 & -8.578 & 12.451 \\
\hline & & & Lowest & & & Highest \\
\hline
\end{tabular}

Keterangan: TotCT = Total Comparative Trends

Tabel 13. Rincian Keunggulan Komparatif Trend dari Ekspor Ikan dalam USD.

Table 13. Details of Comparative Trend of Fish Export in USD.

\begin{tabular}{cccccc}
\hline Periode/Period & Linear Equation & $\mathbf{R}^{2}$ & Slope & \multicolumn{2}{c}{ Comparative Trend } \\
\hline $2009-2011$ & $\mathrm{y}=885.11 \mathrm{x}+60213$ & 0.3062 & 885.11 & 7.84046 & highest \\
$2011-2014$ & $\mathrm{y}=-475.63 \mathrm{x}+96360$ & 0.1532 & -475.63 & -4.213216 & \\
$2014-2019$ & $\mathrm{y}=752.76 \mathrm{x}+76657$ & 0.4067 & 752.76 & -14.29533 & Lowest \\
$2019-2020$ & $\mathrm{y}=-1613.8 \mathrm{x}+135383$ & 0.0878 & -1613.8 & & \\
\hline \multicolumn{2}{l}{ Rerata kemiringan garis trend/Average slope } & & -112.89 & & \\
\hline
\end{tabular}

Tabel 14. Rincian Keunggulan Comparatif Trend dari Ekspor Ikan dalam Ton.

Table 14. Details of Fish Export's Comparative Trend in Tons.

\begin{tabular}{cccccc}
\hline Periode/Period & Linear Equation & $\mathbf{R}^{\mathbf{2}}$ & Slope & \multicolumn{2}{c}{ Comparative Trend } \\
\hline $2009-2011$ & $\mathrm{y}=-0.8695 \mathrm{x}+51.771$ & 0.0896 & -0.8695 & -2.318821 & Lowest \\
$2011-2014$ & $\mathrm{y}=-0.0498 \mathrm{x}+54.869$ & 0.0035 & -0.0498 & 0.132809 & Highest \\
$2014-2019$ & $\mathrm{y}=0.0542 \mathrm{x}+36.08$ & 0.0163 & 0.0542 & -14454 & -1.57881 \\
$2019-2020$ & $\mathrm{y}=-0.6348 \mathrm{x}+51.874$ & 0.1218 & -0.6348 & & \\
\hline
\end{tabular}

Tabel 15. Rincian Keunggulan Komparatif Trend dari Ekspor Udang dalam USD . Table 15. Detail of Shrimp Export's Comparative Trend in USD.

\begin{tabular}{|c|c|c|c|c|c|}
\hline Periode/Period & Linear Equation & $\mathbf{R}^{2}$ & Slope & Comparative & Trend \\
\hline $2009-2011$ & $y=1630.1 x+59694$ & 0.6049 & 1630.1 & 1.237404 & \\
\hline $2011-2014$ & $y=2294.6 x+75703$ & 0.7341 & 2294.6 & 1.741823 & Highest \\
\hline $2014-2019$ & $y=-3.8794 x+120356$ & 2E-05 & -3.8794 & -0.00294 & Lowest \\
\hline $2019-2020$ & $y=1348.6 x+120217$ & 0.1656 & 1348.6 & 1.023718 & \\
\hline \multicolumn{2}{|c|}{ Rerata kemiringan garis trend/Average slope } & & 1317.355 & & \\
\hline
\end{tabular}


Tabel 16. Rincian Keunggulan Komparatif Trend dari Ekspor Udang dalam Ton. Table 16. Detail of Shrimp Export's Comparative Trend in Tons.

\begin{tabular}{crrrrr}
\hline Periode/Period & Linear Equation & $\mathbf{R}^{\mathbf{2}}$ & \multicolumn{1}{c}{ Slope } & \multicolumn{1}{c}{ Comparative Trend } \\
\hline $2009-2011$ & $\mathrm{y}=0.0694 \mathrm{x}+8.6226$ & 0.1716 & 0.0694 & 0.26718 & Highest \\
$2011-2014$ & $\mathrm{y}=0.0888 \mathrm{x}+10.317$ & 0.3832 & 0.888 & 3.418672 & $0.053513 \quad$ lowest \\
$2014-2019$ & $\mathrm{y}=0.0139 \mathrm{x}+12.651$ & 0.0226 & 0.0139 & 0.260635 \\
$2019-2020$ & $\mathrm{y}=0.0677 \mathrm{x}+14.359$ & 0.043 & 0.0677 & & \\
\hline
\end{tabular}

Tabel 17. Rincian Keunggulan Komparatif Trend Ekspor Udang dalam USD. Table 17. Detail of Shrimp Export's Comparative Trend in USD.

\begin{tabular}{cccccc}
\hline Periode/Period & Linear Equation & $\mathbf{R}^{\mathbf{2}}$ & Slope & \multicolumn{2}{c}{ Comparative Trend } \\
\hline $2009-2011$ & $\mathrm{y}=8.4029 \mathrm{x}-326487$ & 0.0587 & 8.4029 & 0.297036 & Highest \\
$2011-2014$ & $\mathrm{y}=100.89 \mathrm{x}+9359.1$ & 0.1085 & 100.89 & 3.566379 \\
$2014-2019$ & $\mathrm{y}=3.5663 \mathrm{x}-138060$ & 0.2195 & 3.5663 & 0.126066 & $0.01052 \quad$ lowest \\
$2019-2020$ & $\mathrm{y}=0.2976 \mathrm{x}+1259.2$ & $9 \mathrm{E}-05$ & 0.2976 & & \\
\hline
\end{tabular}

Comparative trend ekspor ikan dalam ton tertinggi terjadi pada periode 2014-2019 (slope 0.0542) dan terendah pada periode 2009-2011 (slope -0.8695), terlihat pada Tabel 14. Tabel 15 menunjukkan bahwa ekspor udang dalam USD terjadi tertinggi di periode 2011-2014 (slope 2294.6) dan terendah di periode 2014-2019 (slope -3.8794). Pada Tabel 16, trend kenaikan ekspor udang dalam ton tertinggi terjadi di periode 2011-2014 (slope 0.888) dan terendah di periode 2014-2019 (slope 0.0139).
Trend kenaikan impor ikan tertinggi (slope 100.89) dalam USD terjadi di periode 2011-2014 dan terendah (slope 0.2976) di periode 2019-2020 (Tabel 17) sedangkan dalam satuan ton terjadi di periode 2019-2020 (slope 0.0121) dan terendah di periode 2014-2019 (slope -1.00E-08) seperti terlihat di Tabel 18.

Pada Tabel 19 terlihat bahwa trend kenaikan impor udang dalam USD tertinggi ada di periode 2009-2011 (slope 216.09) dan terendah di periode 2019-2020 (slope -106.9).

Tabel 18. Rincian Keunggulan Komparatif Trend Import Udang dalam Ton. Table 18. Details of Shrimp Import's Comparative Trend in Tons.

\begin{tabular}{ccrrr}
\hline Periode/Period & Linear Equation & \multicolumn{1}{c}{$\mathbf{R}^{\mathbf{2}}$} & \multicolumn{1}{c}{ Slope } & \multicolumn{1}{c}{ Comparative Trend } \\
\hline $2009-2011$ & $\mathrm{y}=-0.003 \mathrm{x}+136.26$ & 0.0129 & -0.003 & -1.36364 \\
$2011-2014$ & $\mathrm{y}=-0.0003 \mathrm{x}+23.56$ & 0.0007 & -0.0003 & -0.13636 \\
$2014-2019$ & $\mathrm{y}=-1 \mathrm{E}-08 \mathrm{x}+10.654$ & $2 \mathrm{E}-12$ & $-1.00 \mathrm{E}-08$ & $-4.5 \mathrm{E}-06 \quad$ Lowest \\
$2019-2020$ & $\mathrm{y}=0.0121 \mathrm{x}-524.35$ & 0.1823 & 0.0121 & $5.500006 \quad$ Highest \\
\hline
\end{tabular}

Tabel 19. Rincian Keunggulan Komparatif Trend Import Udang dalam USD. Table 19. Details Comparative Trend of Shrimp Import in USD.

\begin{tabular}{|c|c|c|c|c|c|}
\hline Periode/Period & Linear Equation & $\mathbf{R}^{\mathbf{2}}$ & Slope & Comparat & Trend \\
\hline $2009-2011$ & $y=216.09 x+272.34$ & 0.7637 & 216.09 & 1.89809 & Highest \\
\hline $2011-2014$ & $y=61.514 x+3795.2$ & 0.0453 & 61.514 & 0.540326 & \\
\hline $2014-2019$ & $y=70.81 x+3660.2$ & 0.1004 & 70.81 & 0.621981 & \\
\hline $2019-2020$ & $y=-106.97 x+7016.8$ & 0.0647 & -106.9 & -0.939603 & Lowest \\
\hline
\end{tabular}


Tabel 20. Rincian Keunggulan Komparatif Trend Impor Udang dalam Ton. Table 20. Details Comparative Trend of Shrimp Import in Tons.

\begin{tabular}{lcrrr}
\hline Periode/Period & Linear Equation & $\mathbf{R}^{2}$ & Slope & \multicolumn{2}{c}{ Comparative Trend } \\
\hline $2009-2011$ & $\mathrm{y}=0.0235 \mathrm{x}+0.1174$ & 0.6761 & 0.0235 & 2.473684 Highest \\
$2011-2014$ & $\mathrm{y}=0.0023 \mathrm{x}+0.5777$ & 0.0072 & 0.0023 & 0.242105 Lowest \\
$2014-2019$ & $\mathrm{y}=0.0044 \mathrm{x}+0.4083$ & 0.086 & 0.0044 & 0.463158 \\
$2019-2020$ & $\mathrm{y}=0.0078 \mathrm{x}+0.6422$ & 0.043 & 0.0078 & 0.821053 \\
\hline Rerata kemiringan garis trend/Average slope & & 0.0095 & & \\
\hline
\end{tabular}

Pada Tabel 20 menunjukkan trend kenaikan impor udang dalam ton tertinggi terjadi di periode 2009-2011 (slope 0.0235) dan terendah di periode 2019-2020 (slope 0.0078).

Pada Tabel 21 terlihat bahwa ekonomi kerakyatan di sektor kelautan dan perikanan memiliki prioritas yang berubah seiring perubahan periode kebijakan kementerian. Penjumlahan keunggulan comparative trend ini bisa dilakukan karena adanya kesamaan pola dan logika meskipun mengabaikan $\mathrm{R}^{2}$ dari trend, dan hal inilah yang menjadi keterbatasan dari penelitian ini. Kondisi ketiadaan data atau n.a. (non available) membuat komparasi yang relatif lengkap hanya berhasil dilakukan untuk tiga periode kepemimpinan.

Merujuk pada TAP MPR Nomor XVI/ MPR/1998 yang multi tujuan, tentang 'Demokrasi Ekonomi' yang mengharuskan keberpihakan Indonesia pada 'pengembangan ekonomi rakyat yang mencakup koperasi usaha kecil dan menengah sebagai pilar utama pembangunan ekonomi nasional', (pasal 4), perlu dikaitkan secara keseluruhan dengan perusahaan besar dan investasi asing dan ekspor impor yvaituh dengan pasal 5, 10, 11 dan 12 .
Dari Tabel 21 juga terlihat bahwa tiap skenario ekonomi kerakyatan memiliki periode terbaik yang berbeda-beda. Misalnya, skenario A terbaik terjadi pada periode 2011-2014, Skenario B dan C terbaik terjadi pada 2014-2019 dan D terjadi pada periode 2011-2014.Sebagai catatan, tambahan, maka mulai dari Skenario A analisis koperasi tidak bisa dilakukan karena hanya ada 6 perusahaan koperasi yang berkegiatan produksipenangkapan ikan atau budi daya perikanan (BPS, 2020). Meski demikian, bila Gambar 1 dikaitkan dengan skenario $A$, bila koperasi nelayan di Desa Percut bisa jadi sebuah sampel sederhana (Pratama, 2018), terlihat bahwa koperasi yang $69 \%$ anggotanya adalah nelayan, memiliki kondisi SDM lebih buruk karena 50\% anggotanya hanya berpendidikan $\mathrm{SD}^{9}$. Kondisi ini jauh di bawah kualitas SDM nasional koperasi nelayan produksi seperti di Gambar 1 yang mayoritas SDMnya adalah tamatan SMA $(57,3 \%)$ dan tamatan SDnya hanya $26.2 \%$. Selain rendahnya kualitas SDM koperasi nelayan, nelayan juga merupakan profesi termiskin (Panayotou, 1982 dan MacKenzie, 1979) yang penanggulangan masalahnya membutuhkan upaya pembangunan multi tujuan (Charles dan Yang,1991).

Tabel 21. Ringkasan Implementasi Ekonomi Kerakyatan Seluruh Skenario di Sektor Kelautan dan Perikanan.

Table 21. Summary of All Implementation's Scenarios of the People's Economy in Marine and Fisheries Sector.

\begin{tabular}{cccccccccc}
\hline $\begin{array}{c}\text { Skenariol } \\
\text { Scenario }\end{array}$ & $\mathbf{9 8 - 0 1}$ & $\mathbf{0 1 - 0 4}$ & $\mathbf{0 4 - 0 9}$ & $\mathbf{0 9 - 1 1}$ & $\mathbf{1 1 - 1 4}$ & $\mathbf{1 4 - 1 9}$ & $\mathbf{1 9 - 2 0}$ & $\mathbf{2 0 - 2 1}$ \\
\hline $\mathrm{A}$ & $\mathrm{Na}$ & $\mathrm{Na}$ & 1.97 & -2.71 & $\mathbf{3 . 5 4}$ & 3.52 & $\mathrm{Na}$ & $\mathrm{Na}$ \\
$\mathrm{B}$ & $\mathrm{Na}$ & $\mathrm{Na}$ & 3.21 & 0.29 & 3.13 & $\mathbf{6 . 7 6}$ & $\mathrm{Na}$ & $\mathrm{Na}$ \\
$\mathrm{C}$ & $\mathrm{Na}$ & $\mathrm{Na}$ & 3.67 & 4.16 & 3.96 & $\mathbf{5 . 5 9}$ & $\mathrm{Na}$ & $\mathrm{Na}$ \\
$\mathrm{D}$ & $\mathrm{Na}$ & $\mathrm{Na}$ & $\mathrm{Na}$ & -5.11 & $\mathbf{5 . 3 6}$ & -2.98 & $\mathrm{Na}$ & $\mathrm{Na}$ \\
\hline
\end{tabular}

Keterangan: Huruf tebal merupakan kinerja terbaik di tiap skenario/

Remaks : The number in bold represent the best performance in each scenario) 
Kendala lain studi ini adalah data. BPS sendiri mengatakan bahwa 'data statistik perikanan masih lemah' (BPS, 2019) sehingga hasil komparasi dari pemakaian data yang lemah ini bisa menghasilkan kesimpulan yang kurang akurat. Trend yang baik dari periode tertentu dapat saja terjadi karena dipengaruhi oleh kebijakan periode sebelumnya, dan hal ini belum diperhitungkan dalam penelitian ini. Namun demikian, kita bisa belajar dari semangat Bank Dunia dalam membuat IKB, yaitu terus menerus melakukan penyempurnaan meski melalui proses jatuh bangun sehingga hasilnya dapat disajikan secara terbuka dan bebas diakses oleh umum. Dengan demikian, hasilnya dapat dimanfaatkan banyak pihak, bahkan mempengaruhi pertimbangan strategi para pemimpin dunia dalam menciptakan kemudahan berbisnis.

\section{IMPLIKASI KEBIJAKAN}

Eksperimen ini menunjukkan bahwa ekonomi kerakyatan sesuai dengan sifat politis TAP MPR Nomor XVI/MPR/1998 yang masih bersifat umum, ternyata bisa dirinci pencapaiannya dalam sektor kelautan dan perikanan dalam analisis kurun waktu meskipun ada keterbatasan data. Dengan metode yang sama, penelitian ini bisa direplikasi untuk periodeperiode lain di sektor kelautan dan perikanan maupun untuk di sektor lain terkait evaluasi implementasi ekonomi kerakyatan sesuai TAP MPR yang berlaku umum di seluruh Indonesia, tetapi perlu dimodifikasi sesuai dengan visi misi sektor tersebut. Apabila hasilnya dipublikasi luas secara agregat hasilnya diharapkan mampu menciptakan respon positif tentang perbaikan implementasi ekonomi kerakyatan di Indonesia. Hal ini seperti IKB Bank Dunia, yang menjadi sangat populer di dunia setelah melewati proses jatuh bangun untuk memperbaikinya.

\section{UCAPAN TERIMA KASIH}

\footnotetext{
Penulis mengucapkan terima kasih kepada Universitas Indonesia yang telah memberikan tiga kali grant penelitian dan dua kali grant pengabdian masyarakat. Terima kasih juga ditujukan pada Ibu Pamuji Lestari dan Bapak Budi Sulistio yang membantu penulis mengakses sebagian data yang tidak tersedia di situs web. Penulis juga mengucapkan terima kasih kepada dua reviewer yang namanya tidak diketahui dan telah memberi masukan untuk perbaikan pada artikel ini.
}

\section{PERNYATAAN KONTRIBUSI PENULIS}

Penulis melakukan penelitian ini secara mandiri dengan cara menghitung dari data-data statistik yang ada dan menggabungkannya dengan informasi dari media massa, kemudian menjadikannya menjadi sebuah artikel.

\section{DAFTAR PUSTAKA}

Akuntono, I. (2014, Desember 31). Jokowi Hentikan UKP4 Mulai Hari Ini. (F. A. Permana, Editor) Retrieved 2021 from: https://nasional.kompas. $\mathrm{com} / \mathrm{read} / 2014 / 12 / 31 / 14533821 /$ Jokowi. Hentikan.UKP4.Mulai.Hari.Ini

Aria, P. (2017, May 1). Evolusi Cantrang, Yang di Masa Orde Baru Ramah Lingkungan. (P. Aria, Editor) Retrieved 2021, from katadata.co.id: https:// katadata.co.id/pingitaria/berita/5e9a565855216/ cantrang-orde-baru-masih-ramah-lingkunganini-kkp

Asmara, C. G. (2020, Feruari 21). Kemudahan Bisnis RI No 73, Jokowi Minta ke 40, Bisa? Retrieved from CNBC Indonesia. Retrieved from: https://www. cnbcindonesia.com/news/202002210722094-139464/kemudahan-bisnis-ri-no-73-jokowiminta-ke-40-bisa

Besley, T. (2015). Law, Regulation, and the Business Climate: The Nature and Influence of the World Bank Doing Business Project. Journal of Economic Perspectives, 29(3). DOI: 10.1257/ jep.29.3.99

Capano, G., \& Howlett, M. (2020). The knowns and unknowns of policy instrument analysis: Policy tools and the current research agenda on policy mixes. SAGE Open, 10(1), 1-13. DOI:10.1177/2158244019900568.

Charles, A., \& Yang, C.-W. (1991). A Strategic Planning Model for Fisheries Development. Fisheries Research, 10, 287-307.

Devadiga, J. (2017, November 7). The Ease of Doing Business Index Is Fraught with Flaws. Retrieved September 2, 2020, from fee.org: https://fee. org/articles/the-ease-of-doing-business-index-isfraught-with-flaws/

Domínguez-Escrig, E., Mallén-Broch, F., \& Lapiedra-Alcamí. (2019, October). The Influence of Leaders' Stewardship Behavior on Innovation Success: The Mediating Effect of Radical Innovation. Journal of Business Ethics, 159(3), 849-862. DOI:https://doi.org/10.1007/s10551018-3833-2

Feiock, R. C., Tavares, A. F., \& Lubell, M. (2008). Policy instrument choices for growth management and land use regulation. Policy Studies Journal, 36(3), 461-480. DOI:10.1111/j.15410072.2008.00277.x 
Geva-May, I. (2002). Cultural theory: The neglected variable in the craft of policy analysis. Journal of Comparative Policy Analysis: Research and Practice, 4(3), 243-265. DOI:10.1080/13876980208412682

Geva-May, I., Hoffman, D. C., \& Muhleisen, J. (2018). Twenty Years of Comparative Policy Analysis: A Survey of the Field and a Discussion of Topics and Methods. Journal of Comparative Policy Analysis, 20 (1), 18-35. DOl:https://doi.org/10.1 080/13876988.2017.1405618

Keller, F. B. (2020). Appropriating Democracy: A Comparison Between Argumentative Strategies for Confucian and Islamic Democracy. Journal of Intercultural Studies, 41(2), 180-196. DOI:10.108 0/07256868.2020.1724903

Kelsay, J. (2002). Civil Society and Government in Islam. In S. H. Hashmi, Islamic political ethics: civil society, pluralism, and conflict (Vol. The Ethikon series in comparative ethics). Princeton University Press

Kepustakaan-presiden.perpusnas.go.id. (n.d.). SUSILO BAMBANG YUDHOYONO, Masa Bakti 2004 2014. Kepustakaan-presiden.perpusnas.go.id. Retrieved from: https://kepustakaan-presiden. perpusnas.go.id/cabinet_ersonnel/?box $=$ detail\&id=569\&from_box $=$ list\&hlm=1\&search_ ruas $=\&$ search_keyword $=\&$ activation_ status $=\&$ presiden_id $=6 \&$ presiden $=$ sby

Kepres Nomor 136 pada 10 November 1999 tentang kedudukan, tugas, fungsi, susunan organisasi, dan tata kerja Departemen Eksplorasi Laut

Keputusan Presiden Nomor 147 Tahun 1999 tanggal 1 Desember 1999 tentang Departemen Eksplorasi Laut dan Perikanan

Keputusan Presiden Nomor 165 Tahun 2000 tanggal 23 November 2000 tentang Departemen Kelautan dan Perikanan.

Laurens, N. (2012, December 12). Rokhmin Dahuri, Bekas Menteri yang Pertama Dijerat KPK [Rokhmin Dahuri, Former Minister First Arrested by the KPKJ. Retrieved from JPNN.com:https://www.jpnn.com/news/ rokhmin-dahuri-bekas-menteri-yang-pertama-dijerat-kpk

Liddle, W. R., \& Mujani, S. (2007). Forthcoming. Indonesian democracy: From transition to consolidation. In M. Künkler, \& A. Stepan (Eds.), Democratization and Islam in Indonesia. New York: Columbia University Press

Lodge, M. K. (2014, December). Rational tools of government in a world of bounded rationality. The London School of Economic and Political Science. London: Center or Analisys of Risk and Regulation. Retrieved March 26, 2018, from Center of analysis of risk and regulations, The London School of Economics and Political
Science: https://pdfs.semanticscholarf org/52a2/ 052071dce86579362d0385a8b801f6.pdf

MacKenzie, W. (1979). Rational Fishery Management in a Depressed Region: The Atlantic Groundfishery. Journal of the Fisheries Research Board of Canada , 36, 811-826

Menpan.go.id. (2021, April 22). Menteri Tjahjo Serahkan 'Rapor' SAKIP dan RB Pemda. Retrieved from Menpan.go.id: https://www.menpan.go.id/site/ berita-terkini/menteri-tjahjo-serahkan-raporsakip-dan-rb-pemda

Panayotou, T. (1982). Management Concepts for Small-scale Fisheries. FAO Fish Tech Paper, 228 , p. 53 p

Peraturan Presiden No. 47 tahun 2009 tentang Nomenklatur Departemen Kelautan dan Perikanan menjadi Kementerian Kelautan dan Perikanan

Peraturan Presiden Nomor 29 Tahun 2014 tentang Sistem Akuntabilitas Kinerja Instansi Pemerintah (SAKIP) dan PermenPAN RB Nomor 53 Tahun 2014 tentang Laporan Kinerja Instansi Pemerintah (LAPKIN)

Permana, B. I., \& Mursidi, A. (2020). Peranan Nilai Gotong Royong sebagai bentuk Penerapan Sila Ketiga Pancasila di Desa. Citizenship Jurnal Pancasila dan Kewarganegaraan, 13-20. Retrieved from http://e-journal.unipma.ac.id/ index.php/citizenship

Pratama, F. H. (2018). Analisis Kinerja Koperasi Perikanan Serbaguna di Desa Percut, Kecamatan Percut Sei Tuan, Kabupaten Deli Serdang. Medan: Universitas Muhammadiyah Sumut

Saretzki, T. (2007). The Policy Turn in German Political Science. In F. Fischer, \& G. J. Sidney (Eds.), Handbook of Public Policy Analysis: Theory. Politics and Method (pp. 587- 602). Boca Raton, Florida , USA: CRC Press

Satria, A. (2015). Politik Kelautan dan Perikanan. Yayasan Pustaka Obor Indonesia

Schmidt, V.A. (2011). Speaking of change: Why discourse is key to the dynamics of policy transformation. Critical Policy Studies, 5, 106-126

Sen, A. (2003, October 6). Democracy and Its Globail Roots Why democratization is not the same as Westernization. ,. Retrieved from New Republics: http://www.columbia.edu/itc/sipa/U6800/ readings-sm/sen_democracy.pdf

Solow, R. M. (1985, May). Economic History and Economics. The American Economic Review, 75(2), 328-331. Retrieved from https://www.jstor. org/stable/1805620

Sutari, T. (2017, July 11). Ribuan Nelayan Tuntut Menteri Susi Diganti. Retrieved from CNN Indonesia: Retrieved from: https://www. 
cnnindonesia.com/nasional/2017071106160920-226952/ribuan-nelayan-tuntut-menteri-susi-diganti

TAP MPR Nomor XVI/MPR/1998 tentang Politik Ekonomi Dalam Rangka Demokrasi Ekonomi

Tempo.co. (2003, December 4). Presiden Lantik Jaksa Agung dan Tiga Menteri. Retrieved from: https:// nasional.tempo.co/read/32710/presiden-lantikjaksa-agung-dan-tiga-menteri/full\&view=ok

Trihartono, A., Hara, A. E., \& Iqbal, M. (2018). The Development of Indonesian Maritime Thinking in a Security Perspective. Proceedings of Airlangga Conference on International Relations (ACIR 2018) - Politics, Economy, and Security in Changing Indo-Pacific Region (pp. 635-640). SCITEPRESS - Science and Technology Publications. doi:10.5220/0010281406350640

Warburton, E. (2016). Jokowi and the New Developmentalism. Bulletin of Indonesia Economic Studies, 52:3, 297-320. DOI:10.1080/00074918 .2016.1249262

World Bank. (2020). Ease of Doing Business Scores and Ease of Doing Business Rankings. doingbusiness. org. Retrieved from: https://www.doingbusiness. org/content/dam/doingBusiness/media/AnnualReports/English/DB2018-Full-Report.pdf

Worley, T., Folwell, R. J., \& Mccracken, V. (1993). Methodology For Trend Analysis And Projection Of Production, Market Shares, and Consumption. Journal of Food Distribution Research, 110-117. Retrieved from: https://www.researchgate.net/ publication/23942893

Wright, E. O. (2011a). The 'triadic' model of society in Somers' Genealogies of Citizenship. Socioeconomic Review, 9, 405-418. Retrieved February 25, 2020, from ser.oxfordjournals.org

Wright, O. (2011b). "Genealogies of Citizenship, Markets, Statelessness, and Right to have Rights", . Cambridge University Press, 2008, page xiv. Retrieved from http://www.ssc.wisc.edu/ wright/ Published $\% 20$ writing/Comment $\% 20$ on $\% 20$ Somers $\% 20$ Genealogies $\% 20$ of\%20Citizenship. pdf

Yusuf, A. A., \& Sumner, A. (2015). Growth, Poverty, and Inequality Under Jokowi. Bulletin of Indonesia Economic Studies, 51(3), 323-348. DOI:https:// doi.org/10.1080/00074918.2015.1110685 